\title{
DUE DILIGENCE IN DISCLOSING ENVIRONMENTAL INFORMATION FOR SECURITIES TRANSACTIONS
}

\section{SHAWN H.T. DENSTEDT* and SCOTT R. MILLER**}

Society's increasing awareness of and interest in environmental matters has had a direct effect upon the public offering process. New environmental laws impose increasing obligations upon a company, placing greater demands upon available capital and giving rise to increased concern about current or future environmental obligations. Similarly, the public's interest in, or perception of, the environmental performance of a company may significantly affect the company's ability to raise funds through such an offering. As a result, the disclosure of environmental information is of increased importance to the public, the underwriter, the issuing company and its officers and directors. The process of environmental disclosure is, however. complicated by a variety of factors. Environmental matters are not always easily identified or quantifiable and future environmental effects are difficult to predict. Given such imprecision, issues of materiality are likely to arise. As a result, both the issuing company and the underwriter must ensure that there has been a thorough and complete investigation of existing and potential environmental concerns in order to provide reasonable assurance that the disclosures that are made in the course of a due diligence review are true and that there are no omissions of material facts. This article discusses many of the concerns that arise with respect to environmental disclosure and provides practical examples of the methods and techniques that have been used to ensure "full, true and plain disclosure".

\section{TABLE OF CONTENTS}

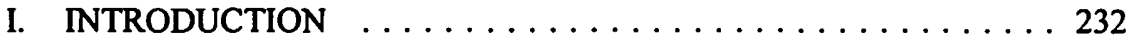
A. THE NEED FOR DISCLOSURE $\ldots \ldots \ldots \ldots \ldots \ldots 233$
B. THE INVESTOR'S INTEREST $\ldots \ldots \ldots \ldots \ldots \ldots \ldots 233$
C. THE UNDERWRITER'S INTEREST
AND OBLIGATIONS $\ldots \ldots \ldots \ldots \ldots \ldots \ldots \ldots \ldots \ldots \ldots$
D. THE COMPANY'S INTEREST
AND OBLIGATIONS $\ldots \ldots \ldots \ldots \ldots \ldots \ldots \ldots \ldots \ldots$
E. THE OBLIGATIONS OF SOLICITORS

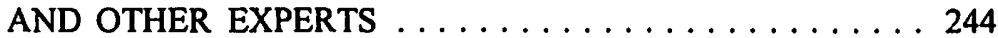

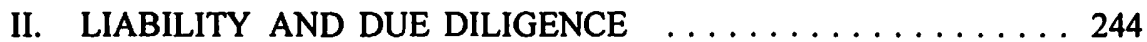

III. THE CHALLENGE OF ENVIRONMENTAL

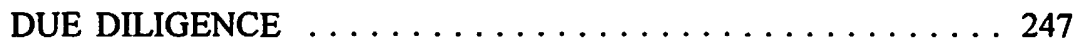

A. ENVIRONMENTAL AWARENESS

AND SOCIETY'S RESPONSE

- Barrister and Solicitor, Bennett Jones Verchere.

- Barrister and Solicitor, Senior Regulatory Counsel, Petro-Canada. The views expressed are those of the authors alone. The material presented in this article may be incorporated into the working knowledge of the reader but its use is predicated upon the professional judgment of the user that the material is correct and is appropriate in the circumstances of a particular use. Where summaries or checklists are provided in these materials, they are provided for reference purposes only. Reliance on them alone to the exclusion of other resources is imprudent since each file is unique and the conduct of the file will depend upon the particular circumstances of the case. When used in actual practice, such guides may be incomplete or overly comprehensive. Note that the checklists and summaries represent the authors' views of the interaction of the law and practice in connection with hypothetical fact situations. The authors would like to thank Susan Anderson, student-at-law with Bennett Jones Verchere, for her research assistance on this project. 


\section{B. THE NATURE OF \\ ENVIRONMENTAL CONCERNS ............. 249 \\ C. PROBLEMS OF QUANTIFICATION \\ AND MATERIALITY . . . . . . . . . . . . . . . . 249}

IV. CONDUCTING A DUE DILIGENCE

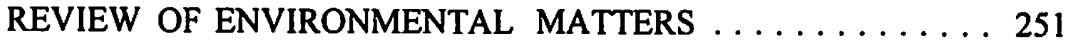

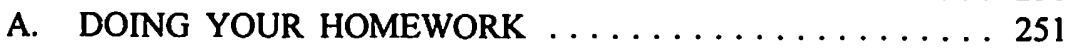

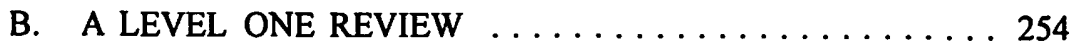

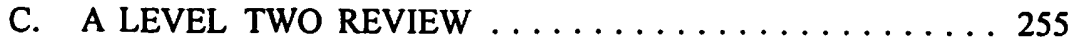

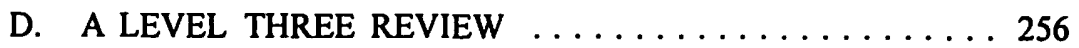

E. AN EXAMPLE OF AN ENVIRONMENTAL

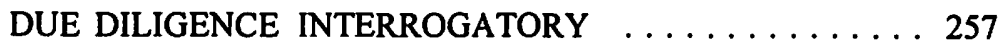

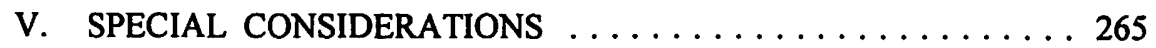

VI. PRACTICAL CONCERNS, TIME LINES, TRANSACTION

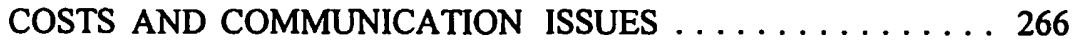

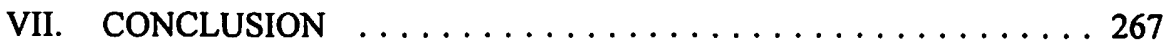

SCHEDULE "A": STELCO INC. ANNUAL

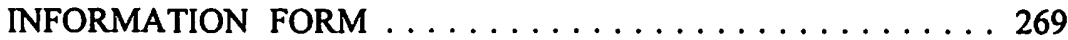

\section{INTRODUCTION}

In Canada and the United States various securities acts require corporations which offer their securities for sale to the public to certify, through their officers and directors, that the information provided constitutes full, plain and true disclosure.' These legislated disclosure obligations were spawned by the abuses and excesses of the securities market in the early part of this century. John Oliver Cunningham provides the following concise illustration of the problem:

[F]ully half of the fifty billion dollars in new securities sold in the United States between World War I and 1930 proved to be worthless by 1933 . This collapse in value resulted in large part from abuses in issuing and trading securities. For example, sellers of securities had deliberately overstimulated the demands of buyers in order to float a mass of essentially worthless stocks and bonds. Promises of easy wealth were made to buyers without disclosing to investors any of the facts essential to estimating the real worth of the securities. The investment literature offered to the public was often misleading and illusory. ${ }^{2}$

Present securities laws responded to these concerns by controlling the nature of the material disclosed and by preventing the dissemination of misleading information. This control and prevention extend to the disclosure of, and the failure to disclose, information relating to modern concerns such as the environmental risks and performance of a company. Although the requirement to report significant environmental risks exists, there has been little comprehensive guidance concerning the identification and evaluation of these matters. This article seeks to provide a contextual 
basis for identifying, quantifying and reporting environmental concerns as a part of these due diligence and disclosure processes.

\section{A. THE NEED FOR DISCLOSURE}

While general disclosure requirements have been a part of securities law for many years, they have typically been more concerned with financial and market risks than with potential environmental liabilities. These general reporting requirements, however, have been buttressed by a plethora of specific reporting requirements, particularly in the United States. ${ }^{3}$ These requirements are not the subject of this article. What follows is a practical review of why environmental liabilities must be addressed, the various peculiarities associated with environmental disclosure and the potential problems that may arise during the process.

\section{B. THE INVESTOR'S INTEREST}

On a rudimentary level it is obvious that each member of the public who wants to acquire a share in an issuer corporation, and thus become an "owner" of the corporation, can (or should) have the right to make the due diligence inquiries of a typical purchaser. While an investor should have this right, it would be impossible and impractical for every share purchaser to exercise such a right. As a result, the law imposes obligations on the issuer and underwriter to certify that disclosure to prospective purchasers has been "full, plain and true". ${ }^{4}$ This obligation requires the issuer to perform the due diligence review that might otherwise be done by prospective purchasers (i.e. the public). In conducting such due diligence work, one question must be uppermost in the issuer's and underwriter's minds: would a reasonable investor attach importance to this information in making an investment decision?

In the United States, the courts have recognized that disclosure acts to equalize the bargaining power between the issuer and the public investors and have therefore accorded it almost constitutional status. In Feit v. Leaseco Data Processing Equipment Corporation, the U.S. District Court stated:

For example, in Canada see Ontario Securities Commission Policy 5.10 (Item 4 of Part II). In the U.S. see items 101, 103 and 303 of Securities Exchange Commission ("SEC") Regulation S-K. In particular see the recent SEC Accounting Bulletin 92 which is critical of the perceived approach of companies to current disclosure obligations. Also see the interpretation of Regulation S-K item 303 in SEC Releases 33-6835 and 34-26831 which require disclosure of environmental liabilities if a registrant cannot demonstrate that the liability is "not reasonably likely" to have a material impact. The obligation to negative a potentiality may be difficult (see "Management Discussion Analysis" below). You should also be cognizant of changes to the Canadian Institute of Chartered Accountants Handbook and the Financial Accounting Standards Board Statement No. 5 in respect of environmental (contingent) liabilities. The U.S. experience is instructive not only as the path which we may be following, but also because Canadian companies register billions of dollars in securities in the U.S. every year. 
The prospective purchaser of a new issue of securities is entitled to know what the deal is all about. Given an honest and open statement, adequately warning of the possibilities of error and miscalculation and not designed for puffing, the outsider and the insider are placed on more equal grounds for arms length dealing. Such equalization of bargaining power through sharing of knowledge in the securities market is a basic national policy underlying the federal securities laws. ${ }^{5}$

While the investor appears to be very much at the mercy of the issuer and the underwriter, she is not without remedies. The various securities acts provide that a failure to make full, plain and true disclosure may give rise to a claim for misrepresentation by an investor who bought shares on the strength of inadequate disclosure. For example, s. 168 of the Alberta Securities Act provides for direct action in damages for misrepresentation against:

(1) the issuer;

(2) each underwriter;

(3) every director of the issuer at the time the prospectus was filed; and

(4) all experts whose consent has been filed, but only to the extent of their opinions.

It is noted that these express statutory remedies are in addition to any other remedies that would otherwise be available at common law. These provisions apply to all securities transactions, including private placements and mergers of businesses.

There appear to be no Canadian authorities in which a shareholder has successfully claimed damages against an issuer or an underwriter for failing to disclose environmental liabilities which affected the value of the shares. The U.S. authorities are difficult to reconcile at this time, both with the Canadian experience and with each other. ${ }^{6}$ In Steiner v. Baxter, ${ }^{7}$ a shareholder is suing the corporation (as well as some of its officers and directors) for manipulating the stock price of the corporation by not disclosing the presence of asbestos in a building owned by a subsidiary of the corporation. The corporation sold the building to an unsuspecting purchaser who later successfully sued the corporation for damages. The shareholder is arguing that the corporation did not disclose the problem in order to make the corporation look sufficiently profitable to issue new stock and debentures in 1985 and thereby artificially inflate the share price. The share price fell from $\$ 21.50$ per share in 1986 to $\$ 4.75$ after the asbestos problem was publicly revealed. The dramatic drop in the price of the shares demonstrates the potential effect upon a company of an adverse environmental

332 F. Supp. 544 at 549 (1971).

In Levine v. NL Industries, Inc., 926 F. 2d 19920 E.L.R. 20197 it was decided that the disclosure obligation did not arise in respect of a company's subsidiary which was operating a uranium processing facility in violation of environmental laws, but in Grossman v. Waste Management, 589 F. Supp. 395 (N.D. Ill. 1984) [hereinafter Grossman], the Court reasoned differently, stating that violations, prior to any enforcement action being taken, may still be material. The inference to be drawn from Grossman is that if existing environmental liabilities would give rise to enforcement action, if known to regulators, they would be material to an investor in making an investment decision.

, Colorado 89-M-809. 
condition, while the commencement of the action shows that investors are prepared to make environmental disclosure an issue.

\section{THE UNDERWRITER'S INTEREST AND OBLIGATIONS}

The underwriters of a public offering must ensure that full, plain and true disclosure is made in respect of all matters, including environmental liabilities. That obligation arises under the various securities acts which require underwriters to certify, to the best of their knowledge, information and belief, that the contents of the prospectus constitute full, plain and true disclosure. For example, the Alberta Securities Act provides that:

91(1) If there is an underwriter, a preliminary prospectus and a prospectus shall contain a certificate in the following form, signed by the underwriter who, with respect to the securities offered by the prospectus, is in a contractual relationship with the issuer or security holder whose securities are being offered by the prospectus:

To the best of our knowledge, information and belief, the foregoing constitutes full, true and plain disclosure of all material facts relating to the securities offered by this prospectus as required by Part 8 of the Securities Act and the regulations under it.

(2). If there is an underwriter, an amendment to a prospectus shall contain a certificate in the following form, signed by the underwriter who, with respect to the securities offered by the prospectus, is in a contractual relationship with the issuer or security holder whose securities are being offered by the prospectus:

To the best of our knowledge, information and belief, the foregoing, together with the prospectus dated ...., contains full, true and plain disclosure of all material facts relating to the securities offered by the prospectus as required by Part 8 of the Securities Act and the regulations under it.

(3) Notwithstanding subsections (1) and (2), the Chief of Securities Administration may authorize an agent of an underwriter duly appointed in writing for the purpose by the underwriter to sign the certificate on behalf of the underwriter.

Underwriters are generally not liable for a misrepresentation in a prospectus unless they knew, or failed to make reasonable inquiries to become adequately informed as to, the true value of the shares being offered to the public for sale. In order to avoid liability, the underwriter must be able to prove that he used due diligence in investigating the issuer. In order to fulfil that obligation, the underwriter must carry out some level of independent investigation of the issuer. As stated by Lynn Nicholas:

[T] he underwriter, in order to establish its defense, is not permitted merely to accept at face value the representations of management. The underwriter must question, probe, investigate, verify - play "devil's advocate" with the issuer."

- L. Nicholas, "The Integrated Disclosure System" (1983) 11 Securities Reg. L.J. 3 at 10. 
Often there is significant pressure on both underwriters and their counsel to proceed quickly in order to take advantage of a particular market opportunity. While commercial reality dictates that underwriters must be responsive to their clients, counsel must ensure that underwriters fulfil their statutory obligation to be the defenders of the public interest. The case law on this point is clear.?

In order to prove due diligence, or disprove negligence, an underwriter must conduct such reasonable investigations as are required to ensure that no misrepresentation is made in the prospectus. The underwriter may also retain professionals, either environmental consultants or legal professionals, to render opinions in respect of environmental issues on which he may then rely. In so doing the underwriter may be relieved of liability provided he "had no reasonable ground to believe (and did not believe) that there had been a misrepresentation or that that part of the prospectus did not fairly represent the opinion." 10 If opinions from environmental consultants are relied on, counsel should ensure that the underwriter understands the limitations of the opinion, particularly if it makes broad assumptions based on a limited review. Similarly, legal opinions that an issuer is in substantial compliance should be critically evaluated. It may also be inappropriate for an underwriter to rely on a consultant's report which makes broad assumptions based on a limited review. "Well-qualified" opinions based on broad assumptions are not a substitute for due diligence.

As with the reasonable person standard in negligence, there appear to be no explicit guidelines for underwriters to follow in conducting due diligence investigations. Each offering is unique and will vary with the circumstances of the issuer. One thing, however, is certain: with a growing potential for significant liabilities associated with environmental problems, the underwriter must conduct some level of investigation of environmental issues. That investigation will depend on the size and location of the company, and the nature of the company's business.

Section 168 of the Alberta Securities Act provides an underwriter with a number of defences:

(1) purchaser bought with knowledge of the misrepresentation;

(2) prospectus filed without his knowledge and underwriter gave reasonable notice of this;

(3) before purchase, underwriter, on becoming aware of the misrepresentation, withdrew his consent and gave reasonable notice;

(4) underwriter did not believe, and had no reasonable grounds to believe, that an expert had made a misrepresentation; and

(5) underwriter conducted an investigation sufficient to provide reasonable grounds for the belief there had been no misrepresentation.

11 B.C. Keith, "Legal Due Diligence and Opinions" in the Canadian Institute, Legal Opinions at 146147. 
Nicholas underlines the commercial pressures on underwriters as follows:

The competitive pressures to undertake an issue of securities for a new, previously unfollowed client are great. Without the familiarity with the issuer bred of a longstanding relationship, the underwriter is in a very uncomfortable position with respect to the due diligence investigation of an unfamiliar issuer."

This competitive pressure should not be allowed to interfere with an underwriter's legal obligations. The failure to conduct a proper environmental investigation of an issuer constitutes negligence for which commercial expediency is no defence.

The underwriter's obligations are similar to those of the company's directors, as the standard is one of negligence. These are briefly discussed below in the section on "Liability and Due Diligence". The courts and regulators have seriously considered the nature of the underwriter's obligation. In A.E. Ames \& Co., the Ontario Securities Commission stated:

\footnotetext{
The phrases "to the best of our knowledge and belief" and "full, true and plain disclosure," phrases contained in the underwriters certificate ... are not just pious passages that appear as a matter of form at the end of every prospectus. Each word in both phrases has a specific meaning behind which must lie a course of conduct by an underwriter before he can affirm that. The underwriter stands between the issuer and the public as an independent, expert party in bringing new securities to the market. In a sense, the underwriter and the issuer are joint-venturers, but in another and more important sense they must be adversaries. That is, the underwriter must seek out and question all relevant and material facts concerning the issuer and reasonably ensure himself that these facts are fully and truly set before the investing public. The underwriter cannot and must not merely rely on the statements and opinions of the issuer's directors, officers and counsel. He must make such independent investigation as will entitle him to say "to the best of my knowledge, information and belief...." Certainly, the underwriter will have to, and is entitled to, rely on the issuer and its officers at many points in the investigation, but such reliance cannot be an easy, automatic thing resulting in blithe acceptance at all points, some matters and some circumstances will call for question, challenge and thorough investigation. ${ }^{12}$
}

It is this state of dynamic tension, of concurrent yet divergent interests, that defines the roles of the parties and ultimately, it is hoped, leads to "full, true and plain disclosure". The underwriter is liable for material misstatements in, and omissions from, any securities filing. The underwriter is relieved of liability if it proves "due diligence"; therefore, the due diligence investigation is critical to the full disclosure of material facts and to the protection of the underwriter's interests. As a result the courts have exhorted underwriters to actively seek out material facts and have held that it is not sufficient for the underwriter to merely rely upon management's assertions. ${ }^{13}$ 
The fact is that as the company and underwriters may to some extent be adverse in interest, there will be opportunities for problems and disagreements. The best solution to avoiding acrimonious due diligence reviews lies in co-operative planning and open communication between the parties in order to ensure sufficient understanding and reasonable disclosure.

\section{THE COMPANY'S INTEREST AND OBLIGATIONS}

Generally, the obligations of the underwriters and the company, as the issuer of the shares, are concurrent even though their interests are different. Like the underwriters, the company, and ultimately its directors, who are responsible to ensure appropriate disclosure, may be liable for both common law and statutory civil liability as a result of a misrepresentation contained in the prospectus.

A public company is substantially different from a private company. In a public company individual private investors become a part of the enterprise by investing their capital in the company. These investors also bring with them a different set of values and concerns and they will evaluate the company and their investment in relation to the market. Because individual shareholders will gauge their expectations in relation to the market, the condition of the company relative to its competitors becomes increasingly important. A failure to disclose, or a false or uninformed disclosure, can result not only in potential regulatory sanctions and a shareholder's action for damages, but it may also have the effect of driving away investment.

Securities legislation in general requires that a company issuing securities, in conjunction with the underwriter, prepare a prospectus that provides "full, true and plain disclosure of all material facts" relating to the securities proposed to be issued. ${ }^{14}$ Accordingly, it is the company's obligation to ensure that any potentially important facts are determined, are analyzed and, if found to be material, are then disclosed. It is not difficult to see how environmental concerns could constitute a material fact that requires appropriate disclosure. The obligation to clean-up and restore lands affected by an environmental spill or contamination is an increasing part of current environmental legislation. In many cases, the obligation can extend into the past and the cost of remediating some sites can be in the range of several million dollars. ${ }^{15}$

Arguably, as the party in control of the information, the company, and potentially its signing officers and inside directors, have a greater obligation to determine and evaluate material facts. One method to satisfy the obligation that is imposed upon them expected to have a significant effect on the market price or value of the securities." similarly that British Columbia recently passed the Waste Management Amendment Act, 1993, S.B.C. 1993, c. 25, which can retroactively hold parties that had already cleaned up a contaminated site liable to further clean-up the site to meet new prevailing standards even though they had already met the standards of the day. 
is for the officers and directors to require the company to conduct an investigation in order to provide reasonable grounds for their belief that there has been no material error or omission in the disclosure. To do this the company must conduct its own "due diligence" review of the facts and circumstances of the corporation in order to ensure that the relevant material facts have in fact been identified and will be disclosed. Such a review serves at least three purposes. First, it allows the company to fulfil the requirements for disclosure required or permitted by statute. Second, it allows the company to adequately brief and inform its officers and directors so that they can fulfil their statutory requirements. Third, the completion of such a review may serve as a defence to an action in the event that there is a subsequent allegation of misrepresentation. Given the nebulous and changing nature of environmental matters, any such due diligence review should include the identification and evaluation of any material environmental concerns.

The underwriters, in order to fulfil their own statutory obligations, will conduct a similar but independent "due diligence" review. In order to respond to the questions posed by the underwriters, and in order to be able to reasonably discuss issues such as the materiality of a specific concern or condition, it will be necessary for the company to have completed its own thorough analysis and review before facing the independent queries of the underwriters. The underwriters will be guided in their questions by a need to identify environmental concerns that represent "material facts". They will be interested in those environmental conditions that significantly affect the market price or value of the shares.

Although the various securities acts and associated regulations provide a general requirement for the disclosure of such an environmental "material fact", there is little express guidance in Canada concerning specific environmental due diligence and reporting requirements. Material facts are, however, broader than just balance sheet considerations and will clearly encompass environmental factors. This fact has been judicially recognized in the United States and the logic is equally compelling in a Canadian context. In an article by Gerard Caron, the issue of material facts was addressed in an environmental context:

[M]aterial facts include not only "information disclosing the eamings and distributions of a company but also those facts which affect the probable future of the company." [They may include actual] legal proceedings ... [and] claim[s] threatened against a corporation... [(if the reasonable investigator is likely to attach importance to the particular threat). It may also include a situation] where a corporation has violated the law, and knows it is thereby subject to yet unasserted legal claims. ${ }^{16}$

Caron also noted that "disclosure is important because the potential for corporate liability based on environmental damage is substantial," and referring to Texas Gulf, that "the central goal of the federal securities laws is to ensure that buyers and sellers 
of securities will be adequately informed of material information affecting the value of the securities traded." 17

The lack of specific guidance concerning environmental matters is in sharp contrast to other areas of disclosure such as financial concerns and corporate organization matters. In those areas where extensive reporting requirements are detailed in the relevant acts and regulations, and are addressed through specific forms or policy statements, the lack of express guidance may simply be an indication of the lag time between the legislation and society's interest in the environment or it may be indicative of the state of flux that exists in the field of environmental affairs with respect to identifying and prioritizing environmental concerns.

Notwithstanding the lack of specificity in Canada, it is clear, in the authors' view, that environmental issues fall under those items often referred to in securities legislation as "Other Material Facts". In Alberta, for example, Form 14, Item 32 relating to the contents of a prospectus states that the issue shall include "any other material facts relating to the securities proposed to be offered and not disclosed pursuant to the [other provisions of the form]." Fulfilling this omnibus requirement takes some thought and imagination with respect to items relating to environmental concerns that should be included as part of the disclosure process. In order to meet the general obligation that has been imposed, some assistance may be obtained from a review of the relatively few specific environmental legislative provisions that do exist. These provisions, gathered mostly from American law, tend to categorize a company's environmental disclosure requirements within three areas:

(1) compliance costs;

(2) legal proceedings; and

(3) management's discussion and analysis.

Ultimately, there will be a need to exercise judgment when disclosing environmental factors. As with other disclosure concerns the effect is relative to the size and nature of the company. How well a company can adjust to or absorb an environmental concern is the true test of materiality, rather than the mere existence of the problem itself.

\section{Compliance Costs}

In a paper entitled "Environmental Management Strategies", Albert Hudec states that the only specific environmental disclosure obligation in Canadian rules relates to disclosure of "the financial or operational effect of environmental protection requirements on the capital expenditures, earnings and competitive position of the issuer for the current fiscal year and any expected impact on future years." 18 This requirement relates to both the issuer's business in general and the effect on the industry as a whole.

$17 \quad$ lbid. at 731.

18 "Environmental Management Strategies" (Paper presented at Canadian Institute of Resources Law, University of Calgary, 8-12 June 1992) in Environmental Law: An Intensive Short Course for Practitioners, Vol. 2 at 3 [unpublished]. 
In this category, the company is required to indicate capital costs required to meet existing and reasonably expected environmental laws. In this regard, current initiatives and undertakings to meet existing requirements, such as water treatment facilities and air filtration equipment, that might have a material effect must be disclosed. More challenging is the assessment of future costs. New legislative initiatives, such as the contaminated site requirements found in the recently passed amendments to the British Columbia Waste Management Act, ${ }^{19}$ would have to be assessed and quantified in order to determine their likely impact. If found to be material, the effect of these situation changes would have to be disclosed as part of a company's anticipated compliance costs. The challenge lies in the fact that such an evaluation is speculative and may give rise to differing opinions. The company should be able to demonstrate, however, that it considered the effect of such a future change with respect to its specific operations, that it evaluated the effect on a reasonable basis and that it indicated how the possible concern was determined to be either material or not material. In Canada, the Canadian Institute of Chartered Accountants ("CICA") has specifically stated that, if reasonably determinable, provision should be made in financial statements for future removal and site restoration costs, net of expected recoveries. Where such costs are not reasonably determinable, they may still be subject to comment through "footnote" disclosure.

In the United States, SEC Regulation $\mathrm{S}-\mathrm{K}^{20}$ sets out three principal areas relating to environmental disclosure: the description of the business, legal proceedings and management discussion and analysis. Item 101 of Regulation S-K requires that an issuer provide a general description of the business. As a part of that requirement, the issuer must provide specific disclosure of the material effects that compliance with federal, state and local environmental laws may have upon the capital expenditures, earnings and competitive position of the issuer. As indicated by the Canadian example above, the issuer must disclose any material estimated capital expenditures for environmental control facilities. The SEC has demonstrated its earnestness with respect to policing these requirements. Ruling on In The Matter of United States Steel Corporation, ${ }^{21}$ the SEC found that United States Steel had filed false reports when it failed to disclose significant costs it estimated would be necessary to bring its operations into compliance with federal legislation.

\section{Legal Proceedings}

Item 103 of SEC Regulation S-K also refers to the disclosure of environmental conditions that may affect the corporation as they relate to legal proceedings. The issuer is required to disclose any material pending legal proceedings, including specified proceedings arising under federal or state environmental laws. As well, this item requires disclosure of any administrative or judicial proceeding arising under environmental laws, if such a proceeding is material to the business, if it includes a claim for damages or costs in an amount exceeding 10 percent of the current

Waste Management Amendment Act, supra note 15, s. 2 amending S.B.C. 1982, c. 41. Supra note 3 at 103.

[1979-1980 Transfer Binder] Fed. Sec. L. Rep. at para. 82,319. 
consolidated assets or, finally, if a government authority is a party to the proceeding, unless any of the sanctions arising is expected to be less than $\$ 100,000$.

In Canada there is no such mandatory requirement with respect to disclosing legal proceedings. However, as part of the necessary due diligence work, such proceedings should be reviewed and assessed with respect to materiality. General disclosure requirements require issuers to be aware of any violations of environmental laws or potential actions that could give rise to criminal, quasi-criminal or civil liability. In assessing whether or not such information comprises a "material fact", consideration should be given to a reasonable analysis of not only the direct costs associated with an offence or penalty, but also to indirect costs such as remediation or civil damages that may be substantially greater than any imposed penalty. Legal matters may also impose a further reporting requirement where potential adverse publicity associated with a prosecution and fine could have an impact on the company's public image and its business affairs.

The task of assessing the nature and impact of legal proceedings in relation to environmental matters is complicated by the fact that in Canada there is an overlap of legal jurisdiction over environmental matters. The operations of a sizable Canadian oil and gas corporation, for example, will likely be subject to both federal and provincial environmental laws. On the production side, the company will be subject to resource based conservation and environmental protection laws. If the company carries out refining or marketing operations outside of the western resource provinces it will, conceivably, be subject to thirteen different sets of environmental laws relating to the twelve provincial and territorial governments as well as the laws and policies of the federal government. In addition, municipalities may administer environmental bylaws that can affect the operations of such a company. In some cases, where the company has dealings in the United States, the potential environmental obligations that arise in that jurisdiction must also be considered. U.S. legislation, such as the Comprehensive Environmental Response, Compensation, and Liability Act, ${ }^{22}$ may have a far reaching and material effect on the company's operations even though its involvement in the U.S. is limited.

As well, the company must contend with rapid changes in environmental laws that are being enacted with increasing frequency, a factor that makes decisions on materiality more difficult.

\section{Management Discussion Analysis}

Item 303 of SEC Regulation S-K requires management to discuss the issuer's historical results and its future prospects, including the effect of environmental matters. This requirement is not dissimilar to the general Canadian requirement to disclose industry conditions; the U.S. requirement has been subject to specific evaluation with respect to environmental matters. 
Item 303 is a prospective disclosure requirement that is triggered by any "known" trends, demands, commitments, events or uncertainties that are reasonably likely to have a material effect on the issuer's operating results or financial condition. The purpose of the management discussion and analysis is to allow investors to be aware of management's view of future prospects. The problem that such a requirement imposes is that much of this discussion is speculative. There is little doubt there may be significant corporate implications arising due to future environmental laws; however, determining what are known trends or what constitutes mere aberrations may be a question of timing and good luck. For example, one can only speculate as to the effect upon business operations, and, in particular, the oil and gas industry, of the Canadian government's international commitment to reduce greenhouse gases to 1990 levels by the year 2000 .

In order to provide some direction for this prospective review, in 1989 the SEC provided an interpretive release $\mathrm{e}^{23}$ which that may also assist Canadian companies facing the task of evaluating the effect of a diversity of environmental conditions that may or may not affect their business. The SEC release provided that when evaluating disclosure for the "Management Discussion and Analysis", the issuer should follow a progressive approach:

(1) First, it should be determined whether the known trend, demand, commitment, event or uncertainty is "reasonably likely to occur".

(2) Second, if management cannot confirm that the event is "not reasonably likely to occur" then it must continue to evaluate the effect of such an occurrence on the assumption that it will occur.

(3) Third, disclosure is required unless it is determined that the condition will not have a material effect upon the corporation.

Although there is currently a lack of specificity with respect to environmental disclosure, there is no doubt that the general requirements, coupled with existing specific environmental requirements, make necessary the disclosure of material facts and material changes relating to the environment that may have an effect on the issuer's business. The challenge for a company is to ensure that there is a system in place to identify potential environmental concerns, quantify those concerns and ensure that significant concerns are properly reported in both initial disclosures and annual reports.

In addition to complying with the general prospectus requirements, it is important for companies to be aware that they also must comply with applicable periodic disclosure requirements such as an annual information form ("AIF") or pursuant to Regulation S-K in the United States. The purpose of the AIF is to ensure that the company is providing "relevant background material essential to a proper understanding of the nature of the issuer, its operations and prospects for the future." ${ }^{14}$ Due Investment Company Disclosure, 7 Fed. Sec. L. Rep. at para. 72,436 (18 May 1989). 
diligence, similar to, although not as extensive as, that required in the preparation of a prospectus, may be carried out in order to fulfil such periodic reporting requirements. An example of such a report included in an annual information form by Stelco Inc. is included as Schedule $A$.

\section{E. THE OBLIGATIONS OF SOLICITORS AND OTHER EXPERTS}

The various securities statutes within Canada hold a variety of parties potentially liable for a misrepresentation that occurs in the disclosure. All experts (including lawyers, accountants and engineers) whose consent has been filed with respect to disclosure reports associated with a prospectus may be subject to civil action in damages where a prospectus contains a misrepresentation relating to their opinion or review. It is important that lawyers associated with the process consider their general obligations to their client and to the public at large.

\section{LIABILITY AND DUE DILIGENCE}

In order to provide protection for the consumer, the various securities acts not only prescribe the nature and extent of disclosure but also institute sanctions where a misrepresentation occurs in any disclosure. In relation to a prospectus, the Alberta Securities Act provides a purchaser of securities with a private remedy against a number of parties associated with the misrepresentation in a prospectus. Misrepresentation is defined in paragraph $1(\mathrm{~m})$ of the Alberta Securities Act as follows:

(i) an untrue statement of a material fact, or

(ii) an omission to state a material fact that is required to be stated, or

(iii) an omission to state a material fact that is necessary to be stated for a statement not to be misleading

As this provision clearly indicates, sins of omission are as serious and as actionable as sins of commission. Therefore, it will be necessary for all of the parties associated with disclosure to ensure that reasonable and prudent efforts have been taken, and can be demonstrated, in order to ensure that no material fact has been omitted. This may prove difficult for environmental matters due to the fact that there are likely to be a variety of different jurisdictions involved, each having different standards and obligations. Regarding these problems, the requirement to identify potential concerns, to evaluate them within an appropriate context for the company, and to demonstrate a reasoned response toward materiality will require considerable effort.

In the event that a prospectus contains a misrepresentation, the Alberta Securities Act provides a right of action or a right of rescission pursuant to section 168. Summarized, that section provides for a direct action in damages as follows:

(1) a right of action against:

(a) the issuer;

(b) each underwriter who is required to sign the prospectus;

(c) every director of the issuer at the time the prospectus was filed; 
(d) all experts (such as lawyers, accountants and engineers) whose consent has been filed but only with respect to reports, opinions or statements that have been made by them in the prospectus; and

(e) every person or company, other than those enumerated above, who signed the prospectus;

or

(2) a right of rescission against the issuer, each underwriter who was required to sign the prospectus and any other underwriter of the securities.

An action for rescission must be brought within 180 days following the date of purchase of the securities; however, an action for damages may be brought at any time up to the earlier occurrence of the expiry of one year from the date of purchase of the securities or within 180 days from the date that the purchaser first had knowledge of the misrepresentation. Considering the time limitation imposed with respect to these remedies, it should be noted that they are in addition to any other remedies that would otherwise be available at common law, such as fraud, misrepresentation or mistake, that may well provide for a greater period of time within which to bring an action.

In responding to a misrepresentation, the defences available vary for the parties involved. The issuer of the prospectus is absolutely liable for a misrepresentation and can only avoid liability where it can demonstrate that the purchaser acquired the securities with knowledge of the misrepresentation. ${ }^{25}$ The defences available to directors, underwriters and the other parties involved in the preparation of the prospectus are more numerous and include the defence of due diligence. Section 168 of the Alberta Securities Act sets out the various defences for a director, underwriter or other signatory to the prospectus, and provides that such a party can avoid liability where he can prove:

(1) that the purchaser purchased the securities with knowledge of the misrepresentation;

(2) that the prospectus was filed without the party's knowledge or consent and that on becoming aware of its filing the party promptly gave reasonable notice that it was filed in this manner;

(3) that after the issue of a receipt for the prospectus and before the purchase of the securities by the purchaser, on becoming aware of any misrepresentation in the prospectus the party withdrew his consent to it and gave reasonable general notice of the withdrawal and the reason for it; and

(4) that, with respect to any part of the prospectus purporting to be made on the authority of an expert the party had no reasonable grounds to believe, and did not believe, that there had been a misrepresentation, that the part of the prospectus did not fairly represent the report, opinion or statement of the expert, or that the part of the prospectus was not a fair copy of or an extract from the report, opinion or statement of the expert. ${ }^{26}$ 
Finally, and perhaps of most interest, a director or underwriter may avoid liability where he can prove that he conducted an investigation sufficient to provide reasonable grounds for the belief that there had been no misrepresentation and did not believe that there had been a misrepresentation. ${ }^{27}$

Although a comprehensive discussion of what constitutes the due diligence defence is beyond the scope of this article, some general guidance is found in the case law. In Feit v. Leaseco Data Processing Equipment Corporation, the Court stated:

\begin{abstract}
What constitutes "reasonable investigation" and "reasonable grounds to believe" will vary with the degree of involvement of the individual, his expertise, and his access to the pertinent information and data. What is reasonable for one director may not be reasonable for another by virtue of their different positions. ${ }^{28}$
\end{abstract}

Recognizing that due diligence be judged subjectively having regard to the parties involved, it is important to note that the standard to be applied is a "reasonable" standard and not an extraordinary requirement. Brian Keith, in his article on "Legal Due Diligence and Opinions", suggested the following definition for due diligence:

Such a measure of prudence, activity or assiduity, as is properly to be expected from, and ordinarily exercised by, a reasonable and prudent man under the particular circumstances, not measured by any absolute standard, but depending on the relative facts of the special case. ${ }^{29}$

Bearing in mind this standard for due diligence, environmental concerns should be treated reasonably, as with all other disclosures. It is suggested that

(1) environmental concerns should be reviewed in advance by the company's officers and directors;

(2) concerns should be reviewed by key environmental, operating, financial and legal personnel;

(3) financial implications should be addressed by the audit committee; and

(4) where applicable, professional advisers should be involved in the due diligence process.

These steps will assist in establishing that the due diligence standard has been met and will form the basis of any defence to a claim for damages stemming from misrepresentation.

It is clear from the statutes and the case law that in order to avoid liability where a misrepresentation does occur, the underwriter and the directors must both be able to demonstrate that they undertook investigations which provided reasonable assurance that there had been no untrue statement of a material fact and that no material fact had been omitted. 


\section{THE CHALLENGE OF ENVIRONMENTAL DUE DILIGENCE}

Whereas history and general experience have provided a clearer understanding of the reporting requirements associated with matters such as the nature of the business, properties of the company, the identities of directors and officers, financial information, share capital, material contracts, tax considerations and the business record of the company, the extent and nature of disclosure with respect to environmental matters is not as clear. Environmental disclosure is, in many ways, similar to reporting requirements relating to other prospective areas of the company's operations such as financial forecasts and the disclosure of risk factors. Like these speculative areas, environmental disclosure requires a substantial measure of skill, judgment and considered thought rather than simple information gathering. The challenge of environmental due diligence arises principally from increased public awareness of environmental concerns and from the nature of environmental problems themselves.

\section{A. ENVIRONMENTAL AWARENESS AND SOCIETY'S RESPONSE}

In June of 1988, concern over the environment was the number one issue of concern in Canadian public opinion polls. Although the environment has been moved out of the number one spot by other matters, such as the deficit and unemployment, the public concern remains about the environment. The Canadian public has developed an increasing respect for the environment and is demanding further and better protection through increased penalties, laws and regulatory action. The degree of public concern is typified by a story reported in The Calgary Herald on an Environics poll which indicated that "A large majority of Canadians believe executives of polluting companies should be held personally responsible for their company's actions." ${ }^{30}$ The report also indicated that Canadians want the federal government to increase its action to prevent environmental degradation, and when asked what the federal government should be doing to protect the environment, the top choices were "pass stricter laws" and "enforce laws, get tough!"

Based upon these public concerns, and building upon the experience of the various legal jurisdictions within Canada and the United States, the federal and provincial governments have introduced new environmental legislation. This legislation changes the rules with respect to environmental behaviour and responds to the public's concern over enforcement through the provision of new violations and increased fines and penalties. Similarly, new regulations and requirements carrying additional costs, are imposed upon industry. Where these costs have a significant impact, disclosure to investors may be required. There is no doubt that compliance costs associated with environmental regulations, which may restrict development, limit emissions or impose liability for reclamation and clean-up, can have material effects on the operations of a corporation. 
Fines and penalties may also have an effect. For example, in June 1993, Tioxide of Canada Inc., a chemical producer operating in Québec, was fined $\$ 1$ million and ordered to undertake $\$ 3$ million in conservation work on fish habitats. These penalties were imposed because the company was found guilty of breaching the federal Fisheries $A c t^{31}$ as a result of its pollution of the St. Lawrence River. Such a significant fine was previously unheard of in Canada; changing legislation and public expectations have moved these large penalties from being merely possible to being probable.

New environmental laws expand the range for criminal action and create new opportunities for civil claims. Some specific areas of environmental response found in recent legislative changes include:

(1) increased fines and penalties for violations;

(2) increased investigative and search powers;

(3) an enhanced role in environmental protection and prosecution by the public including requests for investigations, injunctive relief and the creation of statutory causes of action;

(4) mandatory spill reporting;

(5) direct responsibility and increasing liability for environmental offences on the part of officers, directors and employees; and

(6) "profit stripping" provisions and provisions designed to recover investigative costs.

Any one of these could influence a material fact affecting the corporation.

Of increased interest is the fact that proposed legislative changes may create the potential for liability for past operations and procedures as well as for current procedures. Under current and proposed Alberta and British Columbia legislation, liability for past waste generation activities may have a significant adverse effect on a company's current operations due to the imposition of new liability to conduct a clean-up of a contaminated site. Operations that were accepted as meeting the existing legal and industry standard as recently as five years ago may no longer be appropriate and could give rise to increased liability. Proposed changes to British Columbia's Waste Management $A \mathrm{At}^{32}$ will potentially allow the British Columbia Government to impose civil liability for clean-up costs upon parties where the legislative standard has subsequently been changed notwithstanding that the contemporary standard was met. This means that notwithstanding that the company or an individual met the current requirement, where that requirement is subsequently changed, the company or individual will be required to affect clean-up to the new standard or may be liable for the costs associated with such a clean-up. Not only are the rules of the game changing, they are applying to parts of the game that have already been played!

32 S.B.C. 1982, c. 41 as amended by Waste Management Amendment Act, supra note 15, s. 2. 
The public's increased awareness of, and the government's response to, environmental issues, makes it difficult to accurately define the elements of environmental liability which may have a material effect on the current or future operations of a corporation. This lack of precision in evaluating, assessing and forecasting environmental effects has been contributed to by:

(1) the relatively limited experience that corporations have had with respect to enhanced environmental concern and new legislation;

(2) the rapid change and proliferation of legislation affecting criminal and quasicriminal penalties, and civil liability; and

(3) a trend toward variable regulatory requirements to meet specific conditions.

All of these factors have increased the importance of environmental concerns but have not contributed to an increase in the ability to identify, quantify and forecast the effect upon a corporation of a specific environmental concern or the cumulative effects of a number of environmental concerns.

\section{B. THE NATURE OF ENVIRONMENTAL CONCERNS}

Environmental problems, by their very nature, do not lend themselves to easy evaluation and quantification. This increases the difficulty that is associated with identifying, quantifying and projecting the effect that such a problem may have on a corporation. Environmental problems may be hidden or dormant only to become significant at a later date. For example, ground water contamination cannot be easily observed or measured, however, its significance may be material. Whether an underground plume of contamination is heading toward a school yard or heading underneath a roadway may have a substantial influence on whether or not there is a material adverse effect. Past practices that may have been acceptable at one time may prove to be a serious problem today. The lack of a clear definition of environmental concerns means that the process for determining and evaluating those concerns is of increasing importance.

\section{PROBLEMS OF QUANTIFICATION AND MATERIALITY}

Determining whether a particular problem is material is not easy. Constantly changing laws, which require issuers to evaluate prospective problems and re-evaluate past problems, coupled with the already difficult task of identifying and assessing environmental problems, further confuse the issue. In most cases, there will not be one single event or problem that defines a material fact that must be disclosed. Rather, any number of distinct environmental concerns may collectively create a fact that "significantly affects or would reasonably be expected to have a significant effect on the market price or value of the securities." ${ }^{33}$ 
Similar environmental problems in different areas may not be treated in the same manner and may not give rise to the same potential concerns. Hydrocarbon contamination in an area where the ground water is not relied upon to supply potable water may give rise to a different response (and therefore result in different consequences and materiality) than would be the case where potable water may be affected by the contamination. Evaluation of the nature of an environmental concern requires not only an understanding of the laws that are in place but also requires an appreciation of the interplay between local sensitivity, local enforcement, the current state of the art of remediation, and the size and nature of the company. All of these factors will influence whether an environmental concern is considered to be material. A remediation problem facing a major oil and gas company is likely not to be significant, whereas the same problem associated with a junior oil and gas company may be material. In most cases, the disclosed results will represent estimates or opinions concerning the nature and extent of the environmental problems. Given the variable nature of this information, it should be reliable and the parties should be able, as a minimum, to set forth the source of the estimate or opinion and the assumptions used in reaching the result.

Given the imprecision of the tools currently available to evaluate environmental concerns, the underwriter and the company should first attempt to reach agreement, based upon a reasonable evaluation of the facts, as to the significance of the identified problem. This can be facilitated through a preliminary review and meeting or at a later date as a part of the due diligence meetings between the company and the underwriter. The obligation of the underwriter is to seek out and question all relevant and material facts concerning the issuer and to reasonably ensure that these are presented to the public. In fulfilling this obligation, the analysis and evaluation of the company should not be automatically adopted but neither should it be unreasonably ignored. A reasonable review contemplates inspection of the appropriate work undertaken and opinions given by both parties to quantify the problem. Next, the relative importance of the concern is assessed to determine if it is in fact material.

Environmental problems, such as the likely consequences of ground water contamination or the effect of new or anticipated environmental legislation upon company operations may not be easily ascertainable. However, following the process for evaluation set out in SEC item 303 discussed above, ${ }^{34}$ the parties may at least reach agreement over the question of whether to disclose the item even where they disagree with respect to the extent of the problem.

Failing agreement, the parties may seek the advice of an expert and potentially rely upon a comfort letter to address a particular environmental concern and to determine its relevance or materiality. It should be noted that experts may potentially be liable in damages to the purchaser of securities pursuant to a prospectus if there is a misrepresentation contained in the expert's report. Like the directors and the underwriters, the expert will not be liable for the misrepresentation where it conducted 
an investigation sufficient to provide reasonable grounds for a belief that there had been no misrepresentation. ${ }^{35}$

\section{CONDUCTING A DUE DILIGENCE REVIEW OF ENVIRONMENTAL MATTERS}

\section{A. DOING YOUR HOMEWORK}

Before commencing the actual environmental due diligence review, it will be necessary to become familiar with the corporation's business activities, assets, operations and policies. It will also be critical to determine where the corporation carries on business and the legal arrangements pursuant to which it carries on business and holds assets. There are a wide variety of sources from which to gather information on the corporation. Some are:

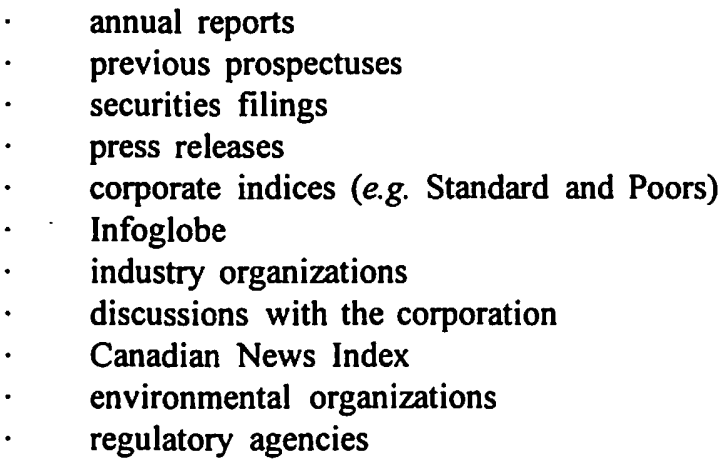

In addition to the traditional sources of public information available to ascertain problem areas, the implementation of the Alberta Environmental Protection and Enhancement Act $(A E P E A)^{36}$ as of September 1, 1993 has resulted in a new source of information. Pursuant to section 33 of the $A E P E A$, most of the information received by the Alberta Department of Environmental Protection, in the furtherance of the purposes of the $A E P E A$, will be disclosed to the public. Accordingly, public scrutiny will attach to:

(1) information forming a part of the Environmental Assessment Process;

(2) information provided to the department in relation to an approval application;

(3) information provided to the department in relation to a certificate of variance;

(4) environmental and emission monitoring data;

(5) operating approvals;

(6) statements of public concern;

(7) Notices of Objection;

(8) reclamation certificates; 
(9) enforcement orders; and

(10) environmental protection orders.

All of these sources will provide a wealth of information for understanding exactly what is the corporation's business. The nature of the corporation's business may be, in and of itself, environmentally risky and thus raise a red flag. One should also be aware of shortcutting the due diligence process for apparently environmentally benign corporations. In one instance, a relatively innocuous retailer had the misfortune of owning a property that was heavily contaminated with lead some years ago. A routine historical title search would have revealed the identity of the long-forgotten owner who had contaminated the property and, because the nature of the previous owner's business was discernible from the registered name on title, raised the appropriate red flags to do more extensive environmental due diligence research. Some "high risk" businesses which may warrant a closer review include:

\section{Waste Disposal:}

sanitary landfill and disposal of dry materials

backfilling using industrial residues

elimination of industrial wastes

snow removal dumps

garbage dumps

disposal of mining residues

Industrial and Commercial Activities:

chemical and petrochemical industry

pharmaceutical industry

pesticide industry

paint and lacquer industry

solvent and recycling industry

pulp and paper industry

metallurgical industry

electrotechnical industry

galvanizing industry

foundries

wood preservation industry

tanneries

naval shipyards

textile industry

coking plant (plant manufacturing artificial gas using coal, tar refining)

fertilizer industry

battery, used oil, liquid waste and barrel recycling plants

service stations

dry cleaners

automobile, bus and subway repair and maintenance workshops

transformer substations (condensers)

oil and gas industry 
Storage and Transfer of Hazardous Substances:

- storage of chemical and petrochemical products

- $\quad$ storage of pesticides

- storage of solvents

- oil pipeline rights-of-way

\section{Scattering:}

scattering of contaminated sediments

scattering of petroleum residues

scattering of sludge from water purification plants or septic tanks

Once the corporation's business is known, all applicable environmental laws and regulations should be reviewed to understand the obligations and potential penalties to which the corporation is or may be subject. It will also be necessary to determine if the corporation is subject to any approvals, permits or licences ("Approvals") relating to the environment. Those Approvals should be reviewed to determine their validity and an environmental consultant retained (if necessary) to determine whether the corporation is in material compliance with the Approvals from a technical perspective.

After determining the potential legal issues that the corporation is facing in respect of the environment, the reviewer should compile a list of areas in which problems might occur, as a guide to things to look for in the due diligence review. Some suggestions are:

\section{Chemicals:}

use and storage

approvals required

use around or near water bodies

how containers are disposed of

use of pesticides etc. contrary to regulations or manufacturers instructions

cleaning of equipment

Historical resources:

- whether any of the property qualifies as a Registered Historical Resource or Provincial Historical Resource

whether the corporation has ever received an order to take certain remedial or protective actions in regard to the above

whether the corporation has ever had a license or permit suspended regarding the above

\section{Miscellaneous:}

any approvals required

recording and reporting requirements

changes without approval

prohibition on transfer of approvals

reporting requirements in approvals (offence to give false information or inaccurate or untrue statements) 
- environmental protection orders, enforcement orders, prosecutions or administrative penalties

remedial obligations

conservation and reclamation required (offsite damage)

contaminated site designation

agreements to remediate

waste handling, manifests, generator numbers

Public Health:

nuisance condition that is or that might become injurious or dangerous to public health

inspection to uncover nuisance, order to comply (e.g. closure, remove nuisance)

any order filed at the Land Titles Office that a health hazard exists

\section{Wilderness Areas:}

areas within or near ecological reserves which prohibit development or which may be the subject of public concern (e.g. ski resorts within natural parks)

Pipelines:

permits

leaks and breaks which must be reported to minister

order for clean-up, or Energy Resources Conservation Board ("ERCB") cleanup and claim for costs

fines

\section{Oil and Gas Conservation:}

suspension of wells if improper activity or equipment

oil clean-up orders, or ERCB clean-up and claim for costs

Depending on the nature of the corporation's business (and what is revealed during the course of the review), the environmental due diligence review can roughly be broken into three basic stages (not to be confused with Phase 1, 2 and 3 Audits).

\section{B. A LEVEL ONE REVIEW}

Level One is the basis for understanding and assessing the corporation's environmental record. The focus of a Level One review is company records and public records. The due diligence process in Level One relies on the accuracy and full disclosure of company records. Public searches through, for example, Alberta Environmental Protection, the ERCB, local court records, Land Titles Office records, MUST (Management of Underground Storage Tanks program), and federally through Environment Canada, should be undertaken. Public offering searches may have to be conducted at agencies across the country and will likely require the cooperation of the issuing corporation. 
Upon completion of a Level One review, one should be in a position to question the corporation about particular problems uncovered during the review, what is being or will be done about the problems, and the significance of the problems. The review is designed to determine, in a general way, the cumulative environmental liabilities affecting the corporation and thus address the "death by a thousand cuts" problem where no one problem is material, but collectively a materiality issue may arise. Some of the documents that should be reviewed are:

(1) all notices, including notices of violation, protection orders or enforcement orders from environment or regulatory authorities having responsibility for environment-related matters;

(2) all correspondence to and from environmental authorities;

(3) all environmental audits, assessments, impact statements, and inspection reports;

(4) all permits and permit applications regarding the environment, amendments and relevant memoranda, and correspondence;

(5) all spill reports, memoranda, responses, notification, and assessments relating to them;

(6) all company policies and procedures regarding environmental matters (e.g. spill response, employee training);

(7) all management review committee reports, memoranda and inter-company correspondence regarding environmental matters;

(8) all consultant and third party environmental audits, reports and correspondence;

(9) capital expenditure reports for pollution control and waste management;

(10) all reports regarding decommissioning, reclamation and abandonment plans and costs;

(11) all insurance policies covering environmental damages and costs;

(12) company and third party investigations, studies and action reports regarding environmental liability;

(13) all reports regarding underground storage tanks and testing procedures;

(14) all company documents revealing procedures to comply with environmental legislation;

(15) all maps and site plans indicating location of underground storage tanks, waste disposal sites, pit boxes, drilling fluid pits, settling ponds, sumps, etc.;

(16) all monitoring reports regarding ground water, surface water, sewer and air emissions for compliance with regulations; and

(17) title documents (e.g. surface leases) regarding restoration, liability for use and historical uses.

\section{A LEVEL TWO REVIEW}

Level Two builds on the Level One review. Whereas a Level One review relies on company and public records, a Level Two review requires more independent analysis. First, additional public searches are made (e.g. municipalities, public health, etc.). Interviews are conducted with managers and senior operational employees at major facilities. Neighbours and local environmental groups may be questioned about particular facilities. Problems revealed by the Level One review may be independently 
assessed (for example where soil contamination is revealed soil tests may be conducted if warranted). A Level Two review may involve some independent environmental review of major facilities by qualified environmental consultants. The Level Two review is designed to move away from dependence on company and public records and, instead, to demonstrate a degree of independent analysis of problems revealed by the Level One review.

\section{A LEVEL THREE REVIEW}

A Level Three review includes Level One and Two reviews and broadens the scope of the review process. Extensive interviews can be conducted with employees, former employees, partners, etc., who may be aware of problems in operations. A Level Three review, which includes a review of company and public records, relies on those records only to establish a base understanding of the company's environmental record and as a road map to independently assess specific areas. A Level Three review will include an independent environmental audit of at least some of the corporation's assets.

In conducting the review one should use the "fountain model" to ensure that the corporation's edicts on environmental matters are being successfully communicated to all levels of the corporation. Some of the corporate-wide policies that should be examined are:

(1) who has ultimate responsibility for environmental matters;

(2) what training programs or manuals the company has in place to address environmental matters;

(3) what are the company's emergency response systems;

(4) whether employees are adequately and accurately trained in company environmental policies;

(5) whether the company conducts regular environmental audits and assessments of its operations;

(6) the types of insurance the company has regarding environmental damage;

(7) the company's policy to limit liability in asset dispositions; and

(8) what the company is doing to improve its public image regarding environmental matters and what activities hurt that image.

As a result of the due diligence review, a mountain of information must be assessed. To ensure the full, plain and true disclosure obligation has been fulfilled, and that all matters which a reasonable investor would consider important are disclosed, information must be critically assessed to determine, first, actual environmental liability and, second, any significant potential environmental liability. Clearly, any review of a corporation's environmental record, and its policies and procedures in that regard, is both sensitive and confidential. Information must be assessed carefully in order to get a complete picture of the corporation's operations. Disclosure that is heavily weighted towards a corporation's efforts to mitigate environmental problems may inadvertently misrepresent significant potential risks that exist. Conversely, a detailed discussion of environmental problems would be equally inappropriate without a corresponding discussion of efforts by the corporation to ameliorate those problems. The result is that 
the reviewer must put itself in the best possible position to understand what information needs to be disclosed and how to best disclose it.

The best way to get to that level of understanding is through an interrogatory process with the corporation. By asking questions arising from the due diligence review, and discussing the answers with the corporation, the reviewer will gain a better understanding of what to disclose. Listed below are some of the questions which might be put to a major integrated oil and gas company during the due diligence process.

\section{E. AN EXAMPLE OF AN ENVIRONMENTAL DUE DILIGENCE INTERROGATORY}

General Questions to ABC Oil Company:

(1) Does ABC own any assets in the United States of America and, if so, is there, or was there ever, a waste disposal site, garbage dump or similar operation located on property now or previously owned by ABC?

(2) Has the U.S.A. Environmental Protection Agency ever named property owned now, previously owned, used or being used, by $A B C$ as a "listed site" requiring clean-up under U.S.A. environmental legislation (e.g. Comprehensive Environmental Response Compensation and Liability Act, or Superfund)?

(3) Has $A B C$ or any of its waste transporters ever been named a "potentially responsible person" under U.S.A. environmental legislation?

(4) What are the details of two violations of Ontario Environmental Protection Act (s. 13) at your ABC Refinery and what are the potential costs of compliance and clean-up, and how were discharges caused?

(5) How will Alberta's (and all provincial governments') policies of stricter enforcement of standards and increased surveillance (evidenced by increases in charges and orders being made) affect $\mathrm{ABC}$ 's operations and costs?

(6) How will the federal government's commitment to freeze $\mathrm{CO}_{2}$ levels at 1990 levels by the year 2000 affect ABC's operations and what is the estimated cost of compliance?

(7) What effect will the potential requirement for higher oxygenation levels in gasoline have on the competitiveness of your products?

(8) What effect will Canada's commitment in the Green Plan to reduce VOCs have on the use of your products?

(9) The CPA/IPAC Report on Oil Spill Preparedness states that the industry does not have the capability to respond to a spill. What is ABC's position? How 
will you deal with oil spills from your sizable oil holdings? What civil liability may arise from such a spill?

(10) The federal government has designated a competitor's site as, basically, a "hazardous site" and has ordered a clean-up. Apparently, ABC may have used the site and be partially responsible for clean-up, so what is ABC's potential liability?

(11) What other sites in Canada may ABC be (or have been) involved with where a clean-up may be ordered?

(12) According to ABC's stewardship report, a "review strategy" is being used in regard to the charges at its facilities. What is ABC's policy regarding environmental violations and compliance?

(13) There is soil contamination at the $A B C$ Refinery site, so what are the potential decommissioning costs of the $\mathrm{ABC}$ Refinery site? What are your plans for decommissioning?

(14) $\mathrm{ABC}$ has removed some contaminated soils to the local landfill sites, so what are the potential risks and costs of this?

(15) Is there ground water contamination at the $A B C$ Refinery site? Is there seepage into any known water body or ground water? Is there a danger of contamination to potable water supplies?

(16) The Anytown facility was closed apparently, in part, to avoid additional environmental costs. What will decommissioning cost? Is $\mathrm{ABC}$ funding the decommissioning or has that liability been passed on to the purchaser? What remaining potential liabilities will there be for $A B C$ ?

(17) ABC plans to phase out (according to its Stewardship Report) a number of bulk stations. What are the potential abandonment/reclamation costs of such an action? What problems will be solved by such action?

(18) With respect to Anywhere facility, problems identified in the audit include infrequent monitoring, no vapour recovery on loading terminal, no contingency plan and poor handling of waste water effluent. What steps have been taken to rectify those problems? How are implementation programs being monitored?

(19) According to ABC's Environmental Audit, ground water contamination from the Anywhere facility is "likely" and may have migrated under the A and B residential areas. Have independent hydrogeological studies been done and if so, what do they show? What is the potential cost of clean-up? What are the potential risks to human health and property values? Are any claims pending? Is any regulatory action pending? 
(20) The Environmental Audit of the Anywhere facility stated that the emergency response plan was inadequate. What has been done to improve the plan?

(21) What is the extent of contamination (heavy metals etc.) in soil and ground water at the Anywhere facility? What is the potential for the site being named a hazardous site? What are the potential decommissioning costs if the site is named a hazardous site?

(22) Has contamination been detected at Anywhere or is there seepage into Lake Anywhere from the Anywhere facility?

(23) Has the effluent system been updated at the Anywhere facility (the audit indicated 65 percent of the time effluent exceeded standards)?

(24) 200 litres of PCBs were stored on site at the Anywhere facility. Are they still stored there? If so, what are the potential risks, what are ABC's plans for the PCBs and what will disposal cost?

(25) There is recognition in the Environmental Audit of the Anywhere Refinery that 1000 kilograms of waste, which contained higher than allowed levels of arsenic, were sent to the Anywhere landfill. Does $A B C$ have reason to believe that it may be liable for clean-up at the landfill? What are the potential costs?

(26) Some shipment of hazardous waste from the Anywhere facility has been by XYZ Chemicals to a U.S. site. Where is the site? Is the site a "listed site" under U.S. Environmental legislation? Has XYZ been named a "potentially responsible person" under U.S. environmental legislation? Who owns the waste when it is shipped? Who owns the waste when it is stored in the U.S. facility?

(27) According to the Anywhere facility audit there were numerous concerns identified: training, monitoring, controls, waste water, non-compliance, stockpiling sludge, emissions, contaminated burial sites and ground water contamination. What has been done to remedy the problems? What are the potential costs of implementing the changes and the potential clean-up costs?

(28) How are decommissioning costs for facilities funded and has ABC estimated what those costs will involve? Please provide estimates and the methodology utilized.

(29) There was a "major" failure of a sump and release of sump fluids in Oil Town. What damage resulted? What were the costs? Was ABC fined or is civil or criminal action pending? What costs may arise from a finding of liability?

(30) Do tankers supplying crude to ABC comply with the Task Force on Tanker Recommendations?

(31) What is the cost of decommissioning the Oil Town Refinery? 
(32) $\mathrm{ABC}$ has prepared an estimate of abandonment cost liability with respect to well abandonments. Has $\mathrm{ABC}$ conducted any cost estimates associated with: (i) reclamation of oil sands, mining sites, etc.; or

(ii) decommissioning of major facilities (e.g. processing plants, refineries, etc.)?

If so, what are those costs and how will they be paid?

(33) How does $\mathrm{ABC}$ plan to deal with future estimated abandonment/reclamation costs? Have specific funds been set aside? How is the amount calculated? Where are those contingency funds accounted for?

(34) Does $\mathrm{ABC}$ maintain any accounting estimate of environmental costs as a percentage of operating costs; i.e. is there any break-out of:

(i) abandonment costs?

(ii) reclamation costs?

(iii) environmental fines?

(iv) cost of dealing with spills or environmentally based public complaints?

(v) cost of equipment overhauls to meet environmental standards?

(vi) cost of environmental advertising?

(vii) cost of environmental affairs department?

(viii) other environmental costs?

What are they?

(35) What is ABC's standard procedure with respect to environmental liabilities when disposing of assets (i.e. is there a cap on liability for claims relating to those periods prior to disposition, is there price adjustment and no ongoing indemnity, etc.)? Are there other methods of limitation? Does ABC assume any continuing liability after disposition? If so, how much and where does this arise?

(36) Attached are:

(i) ERCB Outstanding Spills Report - ABC

(ii) ERCB Outstanding Spills Report - Oil Sands

(iii) ERCB Outstanding Spills Report - Pipelines

(iv) ERCB Public Complaints Registry

Please provide a brief description of remedial action remaining with respect to the items highlighted on the attached spill reports and the total estimated costs associated therewith.

(37) What are ABC's estimates for anticipated abandonment, retrofitting or decommissioning of $\mathrm{ABC}$-operated bulk stations and distribution terminals?

(38) Is the underground storage tank upgrade program on schedule and on budget? What are the expected costs and timetable for its completion? 
(39) Does $A B C$ have a policy of inspecting underground equipment (tanks and flowlines) when selling service stations? What is the policy? Does it track contaminated areas?

(40) The service station retail operating agreements contain notification requirements of the lessee/operator for environmental matters. What is the frequency of these notifications, and do you consider such frequency of notifications and remedial action required to be similar to your competitors' retail outlets? What methods are used to test for leaking U.S.T.s? Does ABC use the "Vacutech" system?

(41) A majority of ABC's bulk stations, distribution terminals and service stations were acquired from DEF Corporation. What was your evaluation of the quality of these stations from a maintenance and environmental perspective at the time of the acquisition? Is $\mathrm{ABC}$ liable for environmental problems associated with DEF's ownership or is DEF responsible? What indemnities exist and when do they apply?

(42) A number of bulk stations and distribution terminals were noted to have PCBs on site. Have these PCBs been cleaned up? What was done with these materials?

(43) With regard to particular problem areas (i.e. Beaver, B.C.; Moose, Manitoba) are audits proposed with a greater frequency than normal and are follow-up practices more stringently maintained?

(44) $A B C$ owns one hundred bulk plants. Only sixty audits are on file. Are the audits on other plants currently in progress? Are there plans for further audits? If so, when will they be implemented? How does $A B C$ prioritize its audit requirements?

Environmental Corporate Cost:

(45) What is ABC's forecast for environmental capital spending for the next five years and the next ten years? How are these funds being accumulated?

(46) Do you consider this average, high or low for the industry? How do you make this assessment?

(47) Are any reserves allocated for emergency clean-up or response?

(48) To what extent does the corporate environmental group confer with ABC's risk managers to determine adequacy of insurance coverage?

(49) What will the effect of proposed changes to environmental laws regarding diesel desulfurization, vapour recovery and production of aromatics have on ABC's operations? At what cost? 
(50) With respect to spill response co-ops, has the increase in the number of accidents and associated increase in costs affected ABC's decisions to remain in such co-ops and what, if any, are ABC's cost burdens respecting this? Do you plan to change your approach?

\section{Secondary Recovery:}

(51) What effects have emissions from the secondary recovery plant had on soil, vegetation, aquatic life, wildlife and public health in the area? How has this been ascertained?

(52) Specifically, what effects have $\mathrm{SO}_{2}$ emissions had on the area and how far afield have tests been conducted?

(53) What improvements have been made at the plant to reduce $\mathrm{SO}_{2}$ and other emissions and what has been the reduction?

(54) Are the $\mathrm{SO}_{2}$ removal processes at the plant the "best available technology" and if not, why not?

(55) How will the federal government's commitments to reduce emission levels of $\mathrm{NO}_{2}, \mathrm{CO}_{2}, \mathrm{SO}_{2}$ and VOCs affect operations at the plant? Will plant upgrading be required and if so, at what cost?

(56) Do levels of particulates being emitted at the plant (e.g. vanadium and nickel) exceed provincial limits and what effects do those emissions have on the environment?

(57) Is the tailings pond currently adequate to meet the future demands of the plant and what contingency plans have been developed to provide for a failure of the tailings pond?

(58) What are the abandonment and reclamation plans for the secondary recovery plant and what is the estimated cost?

(59) How has wildlife been protected from exposure to contamination caused by the plant?

(60) What studies have been done in the last two years as to the effects of the plant and waste water emissions on Oilspill Creek and Pristine Lake? What were the results?

(61) What chemicals are held in the tailings pond? How will these chemicals be disposed of? When will they be disposed of? What is the likely cost? Where is that cost evaluated? 
Pipeline Station:

(62) What damage to the ecosystem was caused by the discharge of waste water into the Big Muddy River at Pipeline System and what was the cost of cleanup and remedying the problem to avoid future discharges?

(63) Was Environment Canada involved? Were any orders issued or charges laid?

(64) Has the discharge affected downstream water users? Are there any potential civil suits?

(65) Alberta Environment ordered a "geotechnical evaluation". What were the results?

Big Bulk Station:

(66) Alberta Environment ordered tests of soil, ground water and surface water. What were the results? What are the remediation costs?

Natural Resources and the Environment:

(66) Discuss ABC's outlook for the upstream oil and gas industry over the next few years and the company's overall strategy for this business in relation to environmental issues?

(67) Discuss the company's emphasis on natural gas. What environmental events could cause the company to change its focus?

(68) Describe your participation in frontier projects. What particular environmental problems do they pose?

(69) Discuss the company's asset rationalization program as it relates to environmental concerns.

Petroleum Products:

(70) Does $A B C$ plan any sales of refineries? If so, what proceeds can be expected from those sales and what costs, including environmental clean-up costs, arise?

(71) Please summarize the current state of environmental regulation of your refining assets.

(72) Do any of the company's principal refining facilities require significant capital for environmental expenditures in the next few years? What significant capital expenditures have been made in recent years? 
(73) Describe the planned 1991 and 1992 capital expenditure programs as they relate to environmental concerns.

Counsel:

(74) Please discuss any pending environmental litigation, contingent liabilities or pending regulatory orders or charges.

It must be emphasized that disclosure of potential environmental problems must be handled with great care. While disclosure should be accurate in assessing the risk, the disclosure should avoid unnecessarily "raising a red flag" for regulatory authorities (absent any statutory obligation to disclose) and potential third party litigants. Additionally, unsophisticated investors may be unnecessarily wary of securities being offered that have environmental problems attached to them even though the company has a plan in place to remedy those problems. Judgment and skill will be required to evaluate the bare responses provided to the interrogatories.

Two general headings may be used to assess a corporation's environmental record: actual environmental costs and potential or contingent environmental costs. Under the first heading are costs such as: abandonment, reclamation, decommissioning, costs of compliance with changing environmental regulations, costs of upgrading facilities to new standards, fines and costs of insurance. Many of those costs are certain, being imposed either by statutory obligation or contract. The second heading involves a more subjective approach, but may also reveal the most significant problems: clean-up costs, potential spills, contamination of land and water, potential third party claims, loss of profits if facilities are shut down, and loss of public credibility.

Contingent liabilities present a unique problem. In the U.S., Item 103 of Regulation $\mathrm{S}-\mathrm{K}$ requires that corporations disclose their contingent liabilities for environmental damage. Obviously, the already difficult issue of determining what requires disclosure becomes even more complex in respect of unasserted claims. Three tests are specified in respect of Item 103 disclosure:

(1) the general materiality test;

(2) the ten percent of current assets test (requires aggregation of similar proceedings); and

(3) the $\$ 100,000$ test (applies only to government proceedings; no aggregation).

Gerard Caron states that "the presence of any of these factors triggers the disclosure requirement with respect to impending or known contemplated proceedings." ${ }^{37}$ The SEC's release in $1989^{38}$ is also applicable to contingent liabilities. First, a corporation must determine whether the contingent liability is "reasonably likely to occur." If the corporation is unable to reach a conclusion that the contingent liability is "not 
reasonably likely to occur" it must evaluate that contingent liability on the assumption that it will occur and then determine whether it will have a material effect on the corporation.

Existing contamination, revealed by an environmental audit, which might give rise to both regulatory and civil action, may require disclosure. Ironically, absent any statutory reporting requirements, it may be the disclosure itself which crystallizes the contingent liabilities into actual liabilities. Corporations must proceed with caution in analyzing their contingent liabilities and attempt to ensure that sufficient information is available to make an informed decision on their likelihood or materiality.

With regard to contingent liabilities it is necessary to assess the probability of the risks and the corporation's policies which are in place to minimize those risks, in order to assess how the matter is best disclosed.

Some of the U.S. decisions on disclosure may be instructive regarding what to disclose. $^{39}$

\section{SPECIAL CONSIDERATIONS}

The potential for an independent environmental audit was discussed in "A Level Three Review" above. The environmental audit presents particular problems which should be addressed early in the process by the underwriter and the corporation. It will be important for the corporation to ensure that the environmental audit will be confidential and that access to the audit is strictly limited. The corporation will also be concerned that the audit may reveal a problem that will require reporting to the regulatory authorities, remediation or possibly trigger enforcement action. While those concerns are real (and justified), if the preliminary review has revealed a concern that requires further investigation, the corporation has little choice but to investigate in order to comply with its disclosure obligations. In fact, once apprised of the potential problem, the corporation may be bound by its own policy and general standards of due diligence in respect of environmental law to conduct an audit.

See for example In the Matter of the United States Steel Corporation, supra note 21. United States Steel Corporation failed to disclose that it would have to make significant expenditures to comply with the Clean Air and Clean Water Acts as revealed by its own studies. The SEC stated that disclosure of these estimates were required. Query: Are potential future compliance costs under new environmental regulations (both federal and provincial) required to be disclosed? See also In the Matter of Occidental Petroleum Corporation [1980 Transfer Binder] Fed. Sec. L. Rep. para. 82,622. Occidental Petroleum Corporation failed to disclose the extent of legal proceedings (and potential financial impact) surrounding its subsidiary Hooker Chemical (the now infamous Love Canal problem). Occidental Petroleum Corporation settled with the SEC but the SEC stated ominously at para. 83,356, with respect to companies which have no formal environmental management system, that "Oxy did not have in place adequate company-wide methods or procedures which, when used to determine the nature and facts of the company's environmental compliance or to facilitate the development of compliance costs, would have assisted it in meeting its disclosure obligations." See also Re Union Carbide, 648 F. Supp. 1322 (S.D.N.Y. 1986). 
Generally, the corporation will also be reluctant to provide existing audits for due diligence review if they were prepared in a manner which would permit a claim of solicitor-client privilege, for fear of potentially losing that claim for privilege should the matter end up in litigation. The corporation that has obtained an audit in respect of a specific problem and that hopes to cloak it with solicitor-client privilege will be in a very difficult position. It may be that if the problem is of such a nature that a reasonable investor would consider it important in making his investment decision, then not only should the audit be provided for the due diligence review, which would eviscerate the claim of privilege, but the problem should also be disclosed in the prospectus. There may, however, be methods available to avoid the problems associated with such disclosure. As the audit itself does not change the underlying facts, but rather just gathers the concerns together and provides suggested responses, other sources of information could be used to obtain the same result.

The retention of an independent consultant to conduct an environmental audit would likely arise where a review of the company's internal documents, a discussion with regulatory authorities or company employees, or a unique situtation such as the historical title search referred to above in respect of the retailer, reveals that a potential environmental liability exists and must be defined. The consultant would then be required to conduct an environmental audit of the site to define the extent of the problem and attempt to quantify the associated risks and costs.

Quite apart from an independent environmental audit, part of the due diligence review should include at least a random sampling of site visits to the facilities being reviewed. These site visits should occur after the document review and should include questioning of on-site personnel to determine if corporate policy is followed. The site visits also provide a tangible understanding of the facility and the corporation's operation which cannot be gained by simply reviewing documents. The site visits will also allow independent verification (to some degree) of information provided by the corporation.

Finally, there are independent organizations which may have conducted audits of the facilities under review. Such independent reviews may provide some comfort, but are less sastisfactory than retaining a private independent consultant. For example, the International Loss Control Institute conducts audits of facilities (which are generally occupational health and safety audits) and has a rating system which provides a quick reference on which the due diligence reviewer can rely.

\section{PRACTICAL CONCERNS, TIME LINES, TRANSACTION COSTS AND COMMUNICATION ISSUES}

One of the biggest practical concerns in any type of due diligence review is the amount of time that is available to conduct the review. If time is limited, as it often is in public offerings, the reviewer must make a judgment call as to what is most important and what is relevant. At the same time disclosure obligations must not be contravened and due diligence inquiries must be both reasonable and prudent. Many of the document searches and public searches should be commenced as early as possible 
in the due diligence process. This means that the whole due diligence framework must be in place as soon as possible. Many environmental searches with regulatory authorities take a long time to produce results (for example, up to and exceeding thirty days with the Ontario Ministry of the Environment).

Increased due diligence for environmental matters means increased transaction costs. Those transaction costs may further increase if a preliminary review reveals a potential environmental problem which requires detailed site investigations, or sampling and analysis. For example, a relatively thorough and detailed analysis of soil and ground water contamination at just three well sites recently cost over $\$ 150,000$. The reviewer must selectively approach such tests.

In order for the due diligence review to proceed smoothly, and for the corporation to ensure that it and its employees are properly protected, all requests for information should be made by one person representing the underwriter to one person representing the corporation. In that way both parties know exactly what is being done and can manage and delegate the work appropriately in order to ensure that answers are provided in a reasonable manner. This process should avoid duplication which may increase the time involved or the transaction costs or both. In addition, while the review must not be guided exclusively by corporate instruction, if the corporation is aware of its obligation to disclose, the corporate officers are invaluable in refining what is relevant and explaining the corporate record.

The following key points should be considered:

(1) Site visits are expensive. Use them only when there is an appropriate concern.

(2) It will likely be impossible to review all reports, audits and compliance records. The reviewer should approach this work judiciously and set up a reasonable method to sample the available material or prioritize concerns.

(3) Not all companies are the same. The reviewer should concentrate on matters that are material given the size and nature of the company.

(4) The cost of the due diligence review should be reasonable given the nature of the company and the offering.

(5) Ensure that the audit is planned in advance in order to take advantage of any efficiencies that may arise. For example, a session concerning future risk and costs should include both general business concerns and environmental concerns in order to avoid duplication.

Finally, the biggest problem is determining what is and what is not significant or material. As noted above, generally no single environmental problem will be material. It is a matter of assessing the overall environmental record of the company in order to disclose, in general terms, the potential environmental risks.

\section{CONCLUSION}

Disclosure of environmental matters is both complex and difficult. Potential liability associated with environmental matters may not always be identifiable, and if identified 
may not be quantifiable. In addition, the changing demands of society for environmental protection will have a direct effect on the disclosure process. For example, an environmental problem that was not considered material ten years ago because of lack of public awareness may indeed be material to today's reasonable investor. As a result of increased public awareness, there have been myriad legislative responses by all levels of government, with each level imposing new duties and obligations on corporations. The impact of these legislative changes on issuers, though perhaps prospective and speculative, must be considered for their impact on the corporation through disclosure.

Environmental matters, like most other disclosure issues, can only be dealt with properly through the compilation and evaluation of the available information. The authors believe the above procedures provide a rational and coherent framework to approach issues of environmental disclosure and will help to ensure that a thorough and complete investigation of existing and potential environmental concerns is made and that disclosure has been "full, plain and true". 


\section{SCHEDULE "A" \\ STELCO INC. ANNUAL INFORMATION FORM}

April 23, 1990

\section{Environmental Protection}

The Corporation's program to maintain and enhance the quality of the environment in the communities in which its plants operate had involved the expenditure of $\$ 340$ million in capital funds for a variety of control facilities since 1961. Costs to the Corporation to operate these environmental programs at all its plants have averaged $\$ 55$ million per year during the two year period ended December 31, 1989. Stelco considers that it has established or is establishing appropriate reserves to satisfy costs that may be incurred in the future on account of environmental protection programs. As a result of the progressive and changing nature of environmental legislation, the Corporation cautions that it is not at this time able to predict with certainty the nature or amount of expenditures that may be necessitated in the future. Stelco does not believe that its competitive position will be materially adversely affected in this respect.

In recent years, the environmental protection program has incorporated features designed to provide a high level of assurance of environmental performance. Environmental reviews, which are conducted on a three-year cycle, have been carried out at each Stelco plant to audit compliance with respect to legal requirements and Stelco environmental policies. Risk evaluation techniques are being employed to identify and control factors which could lead to environmental incidents. 